\title{
Comparative utilization of phosphorus from sedimentary and igneous phosphate rock by major biotic components of aquatic ecosystem
}

\author{
'D. Chakrabarty \\ Limnology Research Unit, Department of Zoology, Krishnagar Government College, Nadia, West Bengal, India \\ Received 30 April 2006; revised 28 November 2006; accepted 5 Desember 2006; available online 1 January 2007
}

\begin{abstract}
Two laboratory experiments were conducted to evaluate the amount of P utilization from two different types of sparingly soluble phosphate rock by aquatic biotic communities. The first type was Mussoorie Phosphate Rock or MPR (sedimentary in origin) and other was Purulia Phosphate Rock or PPR (igneous in origin). The two trials were with eight different treatment combinations. Among various treatments, fish and Chironomid larvae contributed to some extent in increasing the available sediment phosphate content which in turn increased the soluble reactive phosphate (SRP) of overlying water. Concentration of SRP of overlying water decreased in the treatment with zooplanktons. Depletion of SRP of overlying water due to uptake of orthophosphate by Chlorella was also observed. The sedimentary type phosphate rock proved to be more efficient in releasing phosphate than igneous one.

Key words: Phosphate rock, putilization, fish, chironomid larvae, chlorella, zooplanktons
\end{abstract}

\section{INTRODUCTION}

Phosphorus is the most studied element in aquatic system primarily due to the fact that it is the most limiting factor for primary productivity in water bodies and is essential for living organisms and is not exchangeable with other elements in biological system. It is an important constituent of biological systems and is a macronutrient but its availability is often extremely low (Hupfer, et al., 2004). The effects of Phosphorus in nature are therefore profound. Usually phosphorus occurs in oxidized state, either as ions of inorganic orthophosphate or in organic compounds. Phosphorus in solution is normally considered to be orthophosphate (Soluble Reactive Phosphate or SRP) and is taken by different component members of an aquatic ecosystem. Boyd and Musig (1981) demonstrated that planktons in fish ponds absorbed an average of $41 \%$ of $0.30 \mathrm{mg} / \mathrm{L}$ addition of orthophosphate within 24 hours; however phosphorus that is not absorbed by planktons is rapidly absorbed mud (Hupfer, et al., 2004; Cade-menum, 2005). Pelagic invertebrates not only transform, they can also translocate the recycled phosphorus within the system (Shapiro, 1984). Phosphorus is undoubtedly a recognized nutrient for pond fertilization. Among various phosphatic fertilizers

\footnotetext{
*Corresponding author, Email: debajyoti_chakrabarty@yahoo.co.in Tel./Fax: +91-9434148853
}

naturally occurring phosphate source (Mussoorie Phosphate Rock= MPR and Purulia Phosphate rock= PPR) can easily be used in fish farming ponds and has been amply proved to be an effective fertilizer in carp culture (Chakrabarty, 2006). The problem is its extremely low solubility in water. An attempt has been made here to quantify the difference of phosphorus utilization performances by various biotic members in laboratory condition from a marine sedimentary (MPR) and igneous (PPR) phosphate rock of Indian origin.

\section{MATERIALS AND METHODS}

The chemical composition of MPR and PPR are as follows. The MPR is younger in geologic age than PPR (Table 1) and used as a cheap source of direct application fertilizer in fish farming ponds (Chakrabarty, 2006). In order to determine the extent of P-utilization from MPR and PPR by the major biotic components of the pond ecosystem, two laboratory experiments were carried out. The first experiment (trial-I) was carried out in 31 glass jars in the laboratory in presence of water and MPR all throughout, whereas the second one with water and PPR all throughout in the same manner with the previous one. For the first trial, all the 32 glass jars were filled with ground water and then subjected to following eight treatments in quadruplicate. 
Table1: Chemical data and characteristics of the two apatite sources (MPR and PPR) tested for their comparative efficiency in releasing phosphorus in laboratory condition

\begin{tabular}{lll}
\hline Major constituents \% & MPR & PPR \\
\hline $\mathrm{P}_{2} \mathrm{O}_{5}$ & 21.2 & 21.6 \\
$\mathrm{CaO}$ & 38.5 & 39.4 \\
$\mathrm{Fe}$ & 4.0 & 9.2 \\
$\mathrm{MgO}$ & 5.6 & 5.8 \\
$\mathrm{~S}$ & 4.0 & 9.5 \\
$\mathrm{SiO}_{2}$ & 6.6 & 8.1 \\
$\mathrm{C}($ Organic) & 1.14 & 0.92 \\
$\mathrm{~F}$ & 2.0 & 4.1 \\
$\mathrm{Characteristics}$ & Mussoorie Phosphate Rock & Purulia Phosphate Rock \\
Unit cell dimension, a- axis, $\mathrm{A}^{0}$ & 9.367 & 9.371 \\
Mole ratio ( $\mathrm{CO}_{3}: \mathrm{PO}_{4}$ ) & 0.052 & 0.013 \\
Origin and nature & Marine sedimentary and carbonate apatite & Igneous and fluorapatite
\end{tabular}

(i) Water - (A), (ii) Water + MPR - (B), (iii) Water + Soil - $\left(\mathrm{C}_{1}\right)$, (iv) Water + Soil + MPR - $\left(\mathrm{D}_{1}\right)$, (v) Water + Soil + MPR + Chlorella sp. $-\left(\mathrm{E}_{1}\right)$, (vi) Water + Soil + MPR + Zooplankton - $\left(F_{1}\right)$, (vii) Water + Soil +MPR+ Chironomid larvae $-\left(G_{1}\right)$, (viii) Water + Soil + MPR + Fish - $\left(\mathrm{H}_{1}\right)$.

For the second trial, all the 32 glass jars were filled with ground water and then subjected to above eight treatments in quadruplicate in presence of PPR in the same manner with the previous one.

(i) Water - $\left(\mathrm{A}_{2}\right)$, (ii) Water + PPR - $\left(\mathrm{B}_{2}\right)$, (iii) Water + Soil $-\left(\mathrm{C}_{2}\right)$, (iv) Water + Soil + PPR $-\left(\mathrm{D}_{2}\right)$, (v) Water + Soil + PPR + Chlorella sp. $-\left(\mathrm{E}_{2}\right)$, (vi) Water + Soil + PPR + Zooplankton - $\left(\mathrm{F}_{2}\right)$, (vii) Water + Soil +PPR+ Chironomid larvae $-\left(\mathrm{G}_{2}\right)$, (viii) Water + Soil + PPR + Fish $-\left(\mathrm{H}_{2}\right)$.

Twenty gram of hundred mesh size ground MPR (trial-I) and PPR (trial-II) was placed in each of the experimental jars containing $2.5 \mathrm{l}$ of ground water $(\mathrm{pH}$ 7.2). Chlorella sp. used in this experiment was procured from the laboratory axenic monoalgal culture (Chu-10 medium). When the Chlorella concentration attained about $40 \mathrm{mg} / \mathrm{Lof}$ Chl- a; $10 \mathrm{~mL}$ of such concentrate was dispensed in each experimental jar of treatment combination of $\mathrm{E}_{1}$ and $\mathrm{E}_{2}$. Daphnia sp. was collected from the culture tank and concentrated to150 numbers and used in each jar. Chironomid larvae (average length $0.5 \mathrm{~cm} \pm 0.025$ ) were locally procured and then acclimatized in the laboratory prior to their use in experiment $\left(\mathrm{F}_{1}\right.$ and $\left.\mathrm{F}_{2}\right)$. Thirty Chironomid larvae were used in each glass jar of treatment combination of $\mathrm{G}_{1}$ and $G_{2}$. Advanced fry of Oreochromis mossambicus ( $4.20 \mathrm{~g} \pm 0.25 \mathrm{~g} ; 4.0 \mathrm{~cm} \pm 0.60$ ) were procured and acclimatized well in the laboratory prior to their use.
Three acclimatized fry was then placed in each glass jar in treatment combination of $\mathrm{H}_{1}$ and $\mathrm{H}_{2}$. Each set of glass jar was sacrificed at 0,7 and 14 day for examination phosphorous contents of water, soil, Chlorella sp. All of them were carefully isolated, dried in hot air oven, grinded and total $\mathrm{P}$ content was measured using the method described by Jackson (1967). Chlorophyll-a (Chl- a) concentration of Chlorella sp. was analyzed following the method described by Vollenweider (1974). Orthophosphate concentration of water was also measured following standard methods (APHA, 2002). The results obtained in this study were statistically evaluated. Kruskal-Wallis one way analysis of variance by ranks was applied to find out the significance of difference among various treatments. Duncan's Multiple Range Test (Duncan, 1955) was also performed to test the significance of difference between every possible pair of treatment of trial-I and trial-II. This experiments were carried out in Dept. of Zoology, University of Kalyani (August 1993) as well as in Krishnagar Government College (August 2004). The results expressed here as mean of two experiments.

\section{RESULTS}

Introduction of fish $\left(\mathrm{H}_{1}\right.$ and $\left.\mathrm{H}_{2}\right)$ and chironomid larvae $\left(G_{1}\right.$ and $\left.G_{2}\right)$ resulted in considerable rise (Figs. 1 and 2 ) of SRP concentration of water ( 0.1825 and 0.1425 $\mathrm{mg} / \mathrm{L})$ and sediments (13.0-12.9 and11.7-11.5 mg kg/L) over other treatments (Figs. 3 and 4). Presence of zooplankton $\left(\mathrm{F}_{1}\right.$ and $\left.\mathrm{F}_{2}\right)$ in the MPR and PPR treatment, on the other hand, caused decline of SRP level of water all throughout. For example, the amount of orthophosphate (SRP) observed on day $0(0.165 \mathrm{mg} / \mathrm{L})$ declined to $0.0985 \mathrm{mg} / \mathrm{Lin}\left(\mathrm{F}_{1}\right)$ on day 7 and finally to $0.065 \mathrm{mg} / \mathrm{L}$ on day 14 . 
Table 2: Results of Kruskal-Wallis one way analysis by ranks $(\mathrm{H})$ and Duncan's multiple range test for mean values of SRP concentration of water in trial-I

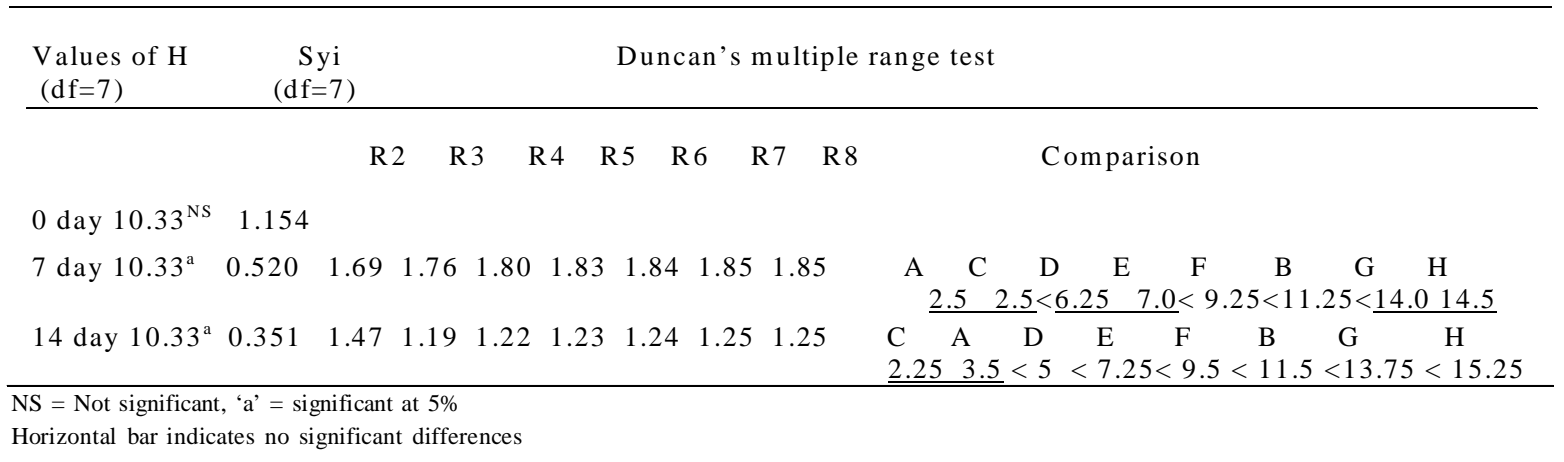

Table 3; Results of Kruskal-Wallis one way analysis by ranks $(\mathrm{H})$ and Duncan's multiple range test for mean values of SRP concentration of water in trial-II

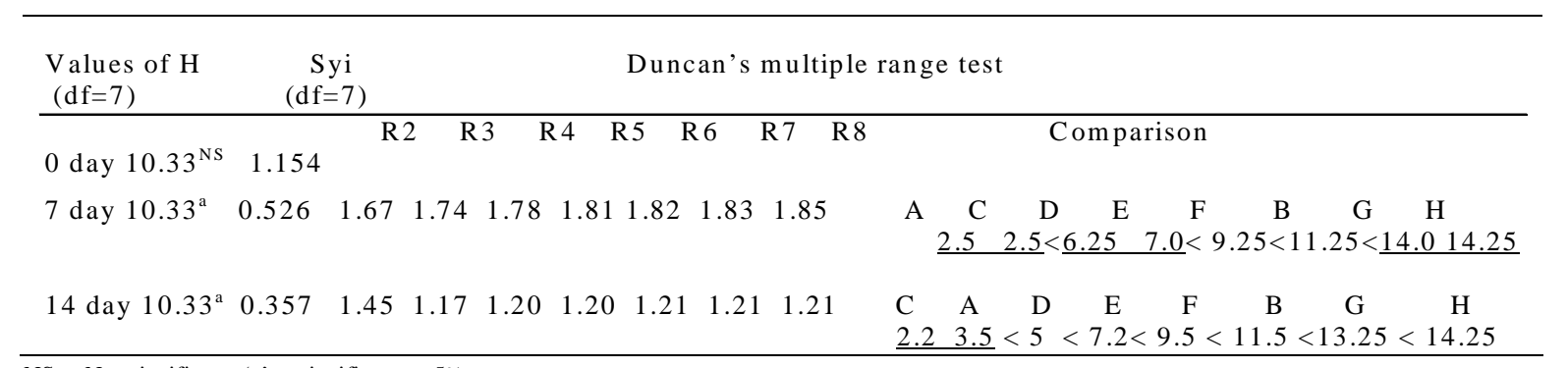

NS = Not significant, 'a' = significant at $5 \%$

Horizontal bar indicates no significant differences

In a same trend the amount of orthophosphate (SRP) observed on day $0(0.125 \mathrm{mg} / \mathrm{L})$ declined to $0.0985 \mathrm{mg} / \mathrm{L}$ in $\left(\mathrm{F}_{1}\right)$ on day 7 ; and finally to $0.065 \mathrm{mg} / \mathrm{L}$ on day 14 in the glass jars with $\mathrm{F}_{2}$ combination. The result was also true for Chlorella sp. the amount of orthophosphate of water in the MPR treatment with Chlorella sp. $\left(\mathrm{E}_{1}\right)$ declined to $0.07 \mathrm{mg} / \mathrm{L} 0.05$ on day 7 and further to $0.045 \mathrm{mg} / \mathrm{L}$ on day 14 , from the initial concentration of 0.165 Similar result was observed with the same treatment combination $\left(\mathrm{F}_{2}\right)$ with PPR (Fig. 2). Glass jars with only water ( $A_{1}$ and $\left.A_{2}\right)$ showed lowest SRP concentration $(0.025 \mathrm{mg} / \mathrm{L})$ of all, all throughout, whereas a stable and relatively high concentration of 0.155 to $0.1425 \mathrm{mg} / \mathrm{Land} 0.125$ to 0.10 of SRP was maintained in the treatment combination of $B_{1}$ and B2. Kruskal-Wallis one way analysis of variance by ranks no significant difference $(\mathrm{H}=10.33$; $\mathrm{P}>0.05)$ of treatment means in the beginning. Statistical analysis, however, showed significant difference $(\mathrm{He} " 14.16$; $\mathrm{P}<0.05)$ among treatments on day 7 and 14 . Six treatment groups such as $\mathrm{G}_{1}$ and $\mathrm{G}_{2} ; \mathrm{H}_{1}$ and $\mathrm{H}_{2} ; \mathrm{D}_{1}$ and $\mathrm{D}_{2} ; \mathrm{E}_{1}$ and $\mathrm{E}_{2}, \mathrm{~A}_{1}$ and
$A_{2} ; C_{1}$ and $C_{2}$ did not differ from each other on day 7 (Tables 2 and 3 ), whereas all the treatment groups expect $\mathrm{C}_{1}$ and $\mathrm{C}_{2} ; \mathrm{A}_{1}$ and $\mathrm{A}_{2}$ showed significant difference on day 14 in both the trial. Significant difference was also found between $H_{1}$ and $H_{2}$ as well as $G_{1}$ and $G_{2}$ in respect of concentration of water SRP and sediment available -P (ANOVA, $\mathrm{P}<0.05$ ) on 0,7 and 14 days of observation. The treatment combination with MPR always showed higher dissolution of $\mathrm{P}$ from insoluble $\mathrm{P}$ than the combination with PPR. The amount of Chl-a concentration (Fig. 5) did not varied significantly (ANOVA, P > 0.05) between the two treatment combination $\left(\mathrm{E}_{1}\right.$ and $\left.\mathrm{E}_{2}\right)$ throughout the experimental period. However, the total amount of phosphorus in chlorella (cell-P) was $0.05 \pm 0.002$ $\mathrm{mg} \mathrm{Jar}^{-1}$ in day 0 of both trial-I and-II. The amount increased to $0.08 \pm 0.002 \mathrm{mg} / \mathrm{Jar}$ (trial-I) ) and to $0.078 \pm 0.003 \mathrm{mg} / \mathrm{Jar}$ (trial-II) on day7 but declined to $0.065 \pm 0.002 \mathrm{mg} / \mathrm{Jar}$ (trialI) and to $0.062 \pm 0.003 \mathrm{mg} / \mathrm{Jar}$ (trial II) in day 14 . The cell-P also did not varied significantly in any day between two series. 


\section{Chakrabarty}

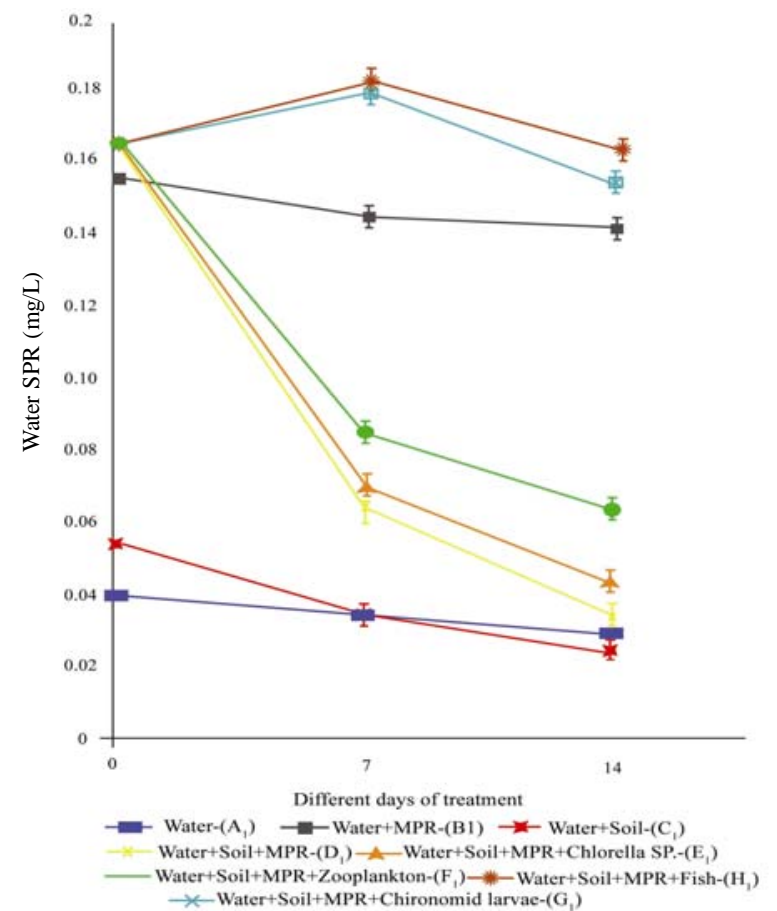

Fig. 1: Mean $\pm S D$ concentration of soluble reactive phosfate of water in different

days of various treatment of trial $\left(\mathrm{H}_{1}\right.$ and $\left.\mathrm{G}_{1}\right)$

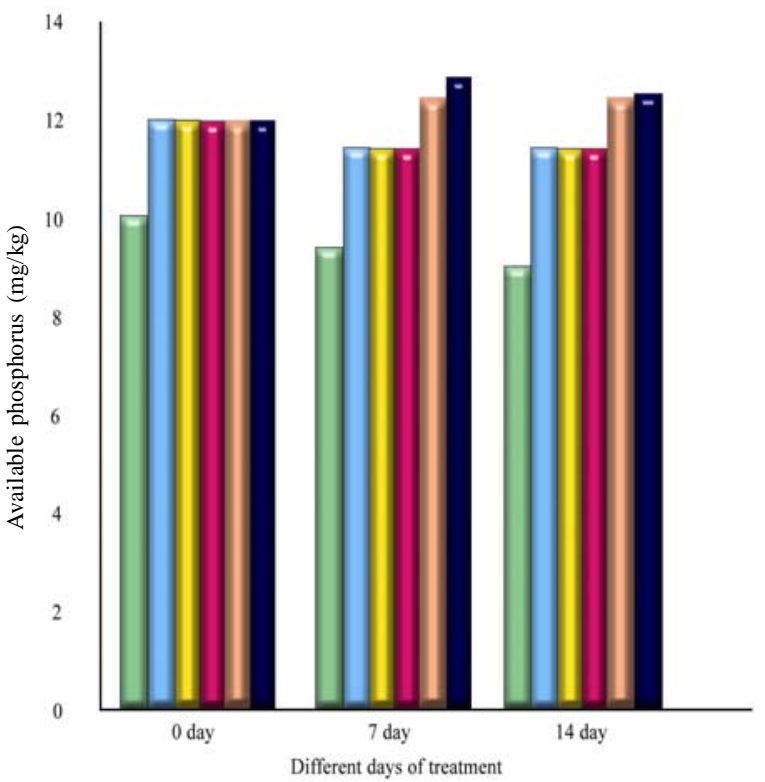

Water+Soil-(C, $) \equiv$ Water+Soil+MPR-(D) - Water+Soil+MPR+Chlorella SP.-(E, $\square$ Water+Soil+MPR+Zooplankton- $\left(\mathrm{F}_{1}\right)=$ Water+Soil+MPR+Chironomid larvae- $\left(\mathrm{G}_{1}\right)$ -Water+Soil+MPR+Fish-( $\left.\mathrm{H}_{1}\right)$

Fig. 3: Mean \pm SD concentration of soluble reactive phosfate of water in sediment of various treatment of trial $\left(\mathrm{H}_{1}\right.$ and $\left.\mathrm{G}_{1}\right)$

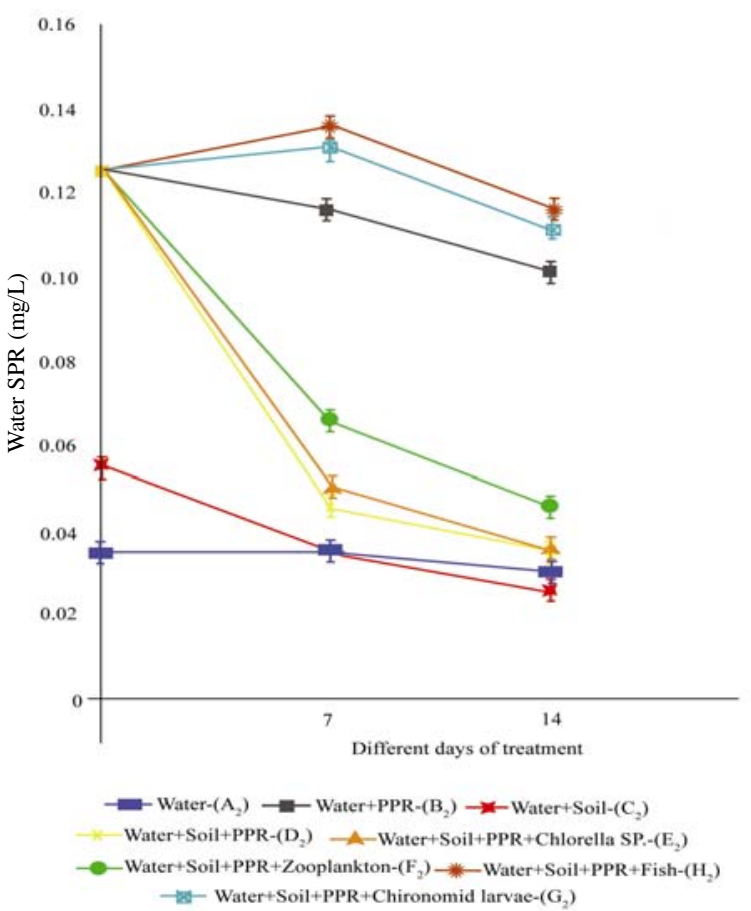

Fig. 2: Mean $\pm S D$ concentration of soluble reactive phosfate of water in different

days of various treatment of trial $\left(\mathrm{H}_{2}\right.$ and $\left.\mathrm{G}_{2}\right)$

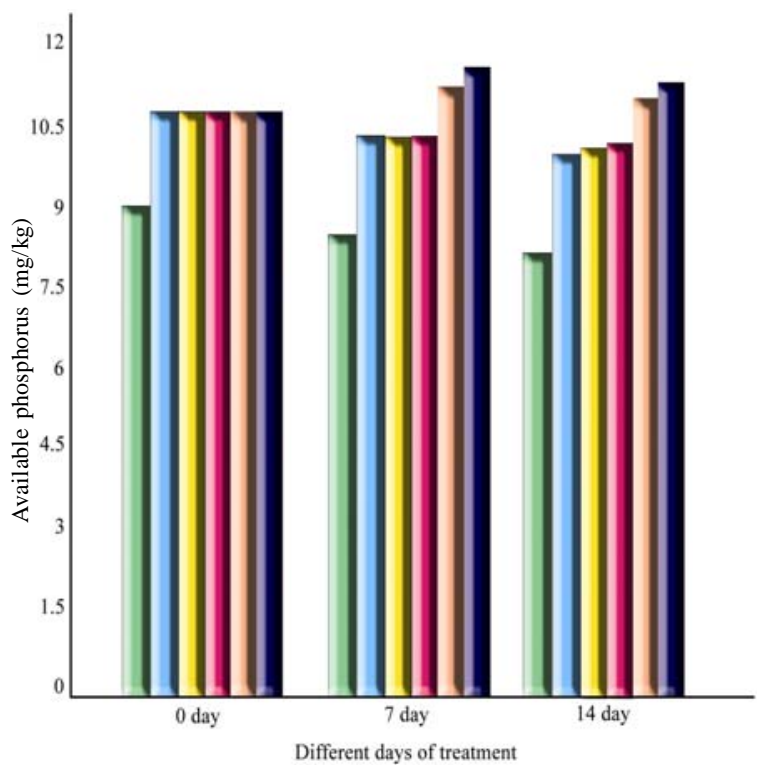

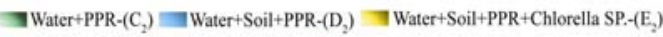
-Water+Soil+PPR+Zooplankton- $(\mathrm{F}$,$) Water+Soil+PPR+Chironomid larvae- \left(\mathrm{G}_{3}\right.$,

Water+Soil+PPR+Fish-(H,)

Fig. 4: Mean $\pm S D$ concentration of soluble reactive phosfate of water in sediment of various treatment of trial ( $\mathrm{H}_{2}$ and $\mathrm{G}_{2}$ ) 


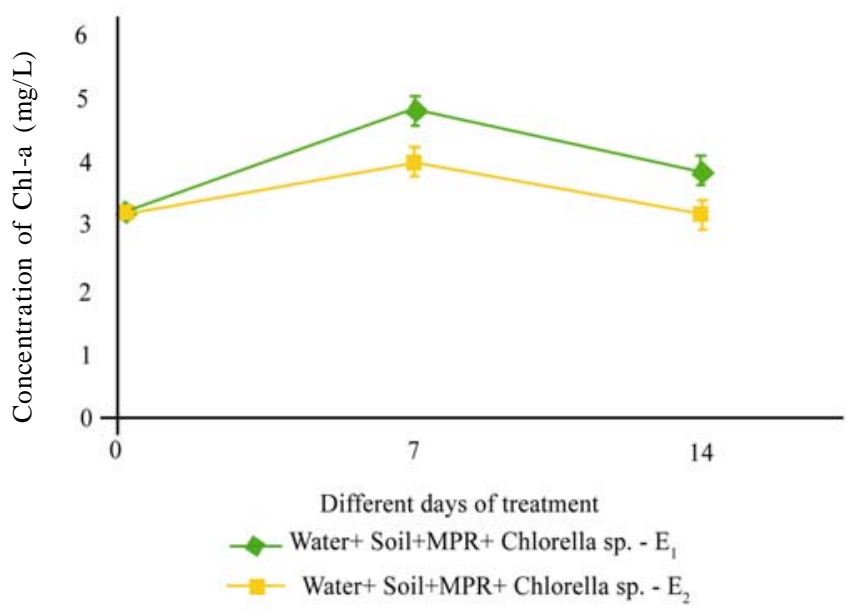

Fig. 5: Mean \pm SD concentration of chlorophyll-a in different days of trial-I $\left(\mathrm{E}_{1}\right.$ and trial-II $\left(\mathrm{E}_{2}\right)$

\section{DISCUSSION AND CONCLUSION}

From the critical examination of the data it is revealed that fish and chironomid larvae contributed to some extent in increasing the available phosphate content of sediment which, in turn, increased the orthophosphate level of overlying water. This was due to their physical disturbance of the bottom sediments which induced the phosphorous release from sediment to the overlying water. The effect was perhaps brought about by the physical disturbance (Petr, 1977) and agitation of sediment enriched with phosphate rock. Similar results were obtained by Gabet, et al., (2003), Schauser, et al., (2003) and Sodergaard et al., (2003). Biomanupulation trials clearly revealed that fish and chironomid larvae had a profound influence in the release of phosphate from otherwise insignificantly soluble phosphate rock by bioturbation (Chakrabarty, 2006). There was an increase in biomass of Chlorella evident from the rise in Chl-a content. The depletion in orthophosphate level of water $\left(0.165-0.07 \mathrm{mg} \mathrm{l}^{-1}\right)$ was due to the phosphorous uptake by the Chlorella. This was evident from the increase in cell-P of Chlorella over time. Phosphorous was found to be a growth regulatory factor of algae by Ahlgren (1988). The critical examination of difference in liberation of available phosphorus from the two sparingly soluble phosphate sources indicated a significant difference $(\mathrm{P}<0.05)$ in treatment combination of $\mathrm{H}_{1}-\mathrm{H}_{2}$ and $\mathrm{G}_{1}-\mathrm{G}_{2}$. This was because of the lesser unit cell dimension $\left(>.008 \mathrm{~A}^{0}\right)$ of MPR than PPR (Table 1) as well as the higher $\mathrm{CO}_{3}: \mathrm{PO}_{4}$ mole ratio of (0.052) of MPR than PPR(0.013). As lesser unit cell dimension and higher $\mathrm{CO}_{3}: \mathrm{PO}_{4}$ mole ratio helps in natural dissolution of phosphate rock in natural condition (PPCL 1987). The utilization of phosphorus by chlorella indicated no significant difference between the treatment combinations of $F_{1}$ and $F_{2}$ Possibly, the amount of SRP was sufficient in both the treatments for algal growth. The concentration of cell $\mathrm{P}$ was also similar between two series. The study clearly indicated that MPR is certainly better phosphate fertilizer than PPR in terms of releasing phosphorus in aquaculture. It also proved that sedimentary phosphate rock has better applicability than igneous type. X- ray diffraction studies identified MPR as carbonate apatite and PPR as fluorapatite. Carbonate apatite is more responsive to natural dissolution than fluorapatite (PPCL, 1987). However, both the fertilizer can be used as direct application fertilizer in fish farming ponds with bottom grazing fishes. These fertilizers are environment friendly and cheap for fish culturist.

\section{REFERENCES}

Ahlgren, G., (1988). Phosphorus as growth regulating factor relative to other environmental factors in cultured algae. Hydrobiol., 170, 191-200.

Boyd, C.E., Musig, Y., (1981). Orthophosphate uptake by phytoplankton and sediment. Aquaculture, 22, 165-173.

Cade-Menum, B., (2005). Using phosphorus-31 nuclear magnetic resonance spectroscopy to characterize organic phosphorus in environmental samples.-In: Turner, B.L., Frossard, E., Baldwin, D.S. (Eds.): Organic phosphorus in the environment, CABI publishing, Wallingford, 21-44.

Chakrabarty, D., (2006). Application of phosphate rock in carp culture. (In Press) 
Duncan, D.B., (1955). Multiple range and multiple F Tests. Biometrics, 1 (1), 1-43.

Hupfer, M., Rübe, B., Schmieder, P., (2004). Origin and diagenesis of polyphosphate in lake sediments: $\mathrm{A}^{31 .} \mathrm{P}$ NMR study. Limnol. Oceanogr., 49, 1-10.

Gabet, J.E., Reichman, O.J., Seabloom, W.E., (2003). The effects of bioturbation on soil process and sediment transport. Ann. Rev. Earth Plan. Sci., 31, 249-273.

Jackson, M.L., (1967). Soil chemical analysis. Prentice hall of India Private Limited, New Delhi.

Petr, T., (1977). Bioturbation and exchange of chemicals in the mud water interface. In Golterman H.L., editor Interactions between sediments and fresh water. Dr. W. Junk B. V., The Hague. 216-226.

PPCL., (1987). MussooriePhos. A natural phosphatic fertilizer for direct application. Pyrites, Phosphates and Chemicals Ltd. New Delhi.

Schauser, I., Lewandowski, J., Hupfer, M., (2003). Decision support for the selection of an appropriate in-lake measure to influence the phosphorus retention in sediments. Wat. Res., 37, 801-812.

Shapiro, J., Carlson, R., (1982). Comment on the role of fish in regulation of phosphorus availability in lakes. Can. J. Fish. Aquat. Sci., 39, 364.

Sødergaard, M., Jensen, J.P., Jeppesen, E., (2003). Role of sediment and internal loading of phosphorus in shallow lakes. Hydrobiol., 506, 135-145.

Standard Methods., (2002). Standard methods for the examination of water and waste waters (21 $1^{\text {st. }}$ Ed.), American Water Works Association (AWWA), Water Pollution Control Federation (WPCF) and American Public Health Association (APHA) Washington DC, USA.

Vollenweider, R.A., (1974). A manual on methods of measuring primary production in aquatic environment. IBP Handbook No. 12, Second Ed., Blackwell Scientific Publications, Oxford, 225

\section{AUTHOR (S) BIOSKETCHES}

Chakrabarty, D., Ph.D, WBES West Bengal Education Service, Reader and head, Department of Zoology, Krishnagar Govt. College, Krishnagar-741101, Nadia, India. Email: debajyoti_chakrabarty@yahoo.com

This article should be referenced as follows:

Chakrabarty, D., (2007). Comparative utilization of phosphorus from sedimentary and igneous phosphate rock by major biotic components of aquatic ecosystem. Int. J. Environ. Sci. Tech., 4 (1), 43-48. 